\title{
CHRONOLOGY OF COASTAL PLAIN DEVELOPMENT DURING THE HOLOCENE IN WEST BELGIUM
}

\author{
Cecile BAETEMAN*
}

\begin{abstract}
Borehole evidence, correlated by means of sedimentary environmental interpretation, linked with age dates from basal and intercalated peat layers yielded the chronology of the development of the coastal plain of West Belgium.

The sea level was close to at least - $18 \mathrm{~m}$ (NAP) at about 8400 B.P. and the formation of tidal flats started as from 8100 B.P. The rapid sealevel rise caused the deposition of only tidal sediments. At 7000 B.P., however, a first peat growth initiated although only restricted in valley-like depressions in the pre-Holocene surface. But between ca 6400 B.P. and 2200 B.P. the entire area was characterized by alternating peat growth and deposition of tidal sediments, reflecting a decrease in the rise of the sea level. Highly favourable conditions for peat formation prevailed between ca 5200 B.P. and 2200 B.P. resulting in an apparent continuous peat accumulation for nearly 3.500 and 2200 14-C years in respectively the landward and seaward part of the area. After ca 2000 B.P. drastic changes in the environmental conditions resulted again in the formation of only tidal deposits.
\end{abstract}

Key-words: Holocene, coastal plain development, sea-level rise, radiocarbon dates, peat, tidal flats.

RESUME

CHRONOLOGIE DE L'EVOLUTION DE LA PLAINE MARITIME DE L'OUEST DE LA BELGIQUE DURANT L'HOLOCENE

De nombreux sondages dont les corrélations sont établies grâce à l'interprétation de l'environnement sédimentaire et à des datations radiocarbone de la tourbe de base et des tourbes intercalaires permettent de retracer l'évolution de la plaine maritime de l'Ouest de la Belgique.

Le niveau de la mer était proche de - $18 \mathrm{~m}$ N.A.P. à environ 8400 B.P. et la formation des wadden débute à environ 8100 B.P. La montée rapide du niveau marin provoque uniquement le dépôt de sédiments tidaux. Cependant, à 7000 B.P., une première formation de tourbe apparaît mais restreinte dans des đépressions de la surface pré-Holocène. Mais entre environ 6000 B.P. et 2200 B.P., la région entière est caractérisée par une alternance tourbe, sédiments intertidaux reflètant un ralentissement de la remontée du niveau marin. Des conditions très favorables à la formation de tourbe existent entre environ 5200 B.P. et 2200 B.P. conduisant à une accumulation, apparemment continue, de tourbe pendant près de 3500 et 2200 années radiocarbone dans, respectivement, la partie continentale et la partie marine de la région. Après environ 2000 B.P. des changements drastiques des conditions environnementales entraînent de nouveau uniquement la formation de dépôts intertidaux.

Mots-clés: Holocène, évolution de la plaine maritime, montée du niveau marin, datations radiocarbone, tourbe, wadden.

\section{1 - INTRODUCTION}

The coastal plain of Belgium is situated along the very southern part of the North Sea. It is protected from the low macrotidal sea by dunes and dikes, and one small river, the IJzer, is crossing it (fig. 1).

Only the western part of the plain bears a thick Holocene sequence in which significant events of coastal development are recorded. In the framework of the systematic mapping of it, a series of new C-14 dates became available, which were recently presented in detail as an IGCP 200 contribution (Baeteman \& Van Strijdonck, 1989).

With the present paper, it is not yet the aim to produce a chronology of sea-level changes on base of the C-14 dates on peat, because it is more important to first understand the synchroneity of changes in the coastal plain as well as to unravel the factors controlling the spatial variability of coastal response.

The reconstruction of coastal development is based on hand- and power-driven boreholes, the latter yielding suitable and sufficient material for age determination on peat. Unlike the current Dutch and former Belgian way of subdividing coastal deposits, peat layers are not used as base for a chrono-or lithostratigraphy. But because of the occurrence of a wide range of sedimentary sub-environments and facies changes, sedimentary environmental interpretation is applied for

* Belgian Geological Survey, Jennerstraat 13, 1040 BRUSSEL, Belgium.

Note présentée lors de la réunion de la sous-commission de l'INQUA: Shorelines of Northwestern Europe d̀ Rennes le 12 septembre 1990. 


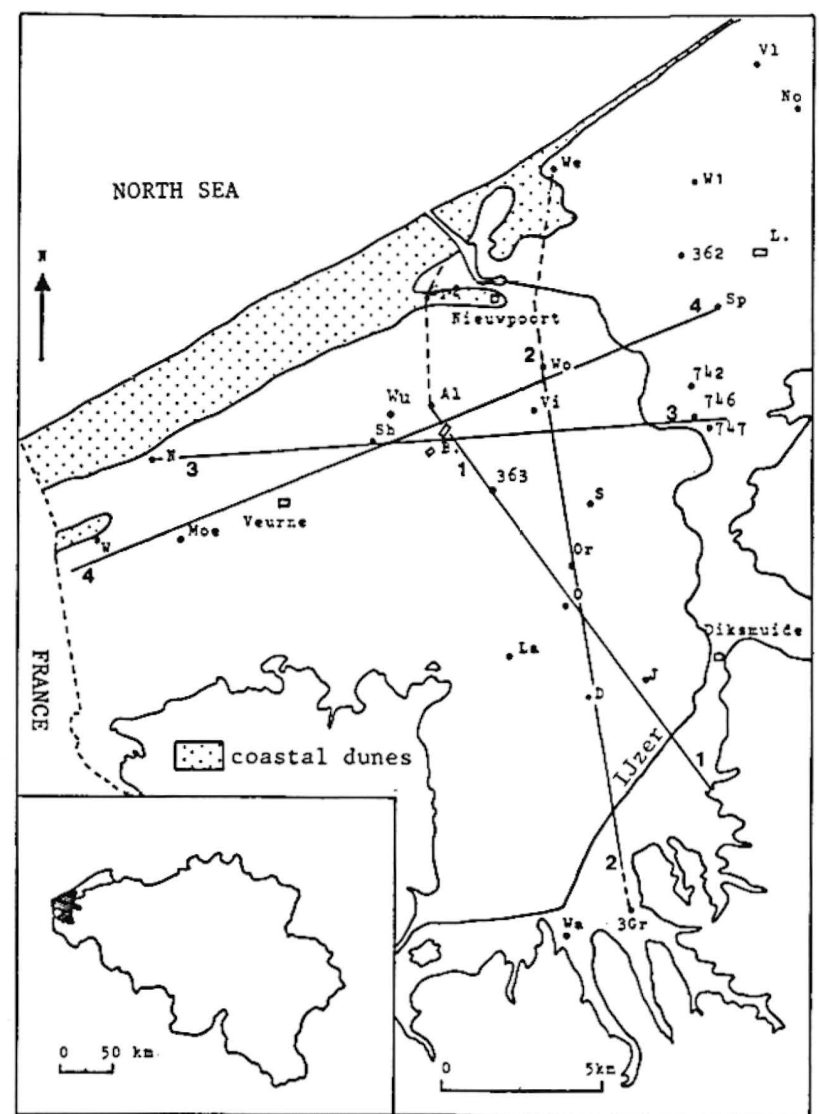

Fig. 1: Western coastal plain of Belgium with location of the C.14 datations, profiles and cross-sections.

Fig. 1: Plaine maritime de l'Ouest de la Belgique: localisation des sondages avec datations radiocarbone, des profits et des coupes.

correlating the boreholes, although here the details are not presented. Only such a method reveals the geometry or spatial distribution of the different sedimentary units, which then can be intergrated in a lithogenetic classification. The chronology of the peat layers linking the lithogenetic classification reveals the general sequence of events and ultimately the interpretation of the Holocene coastal development.

\section{2 - STRATIGRAPHY \\ OF THE HOLOCENE COASTAL DEPOSITS}

The coastal deposits represent the major infilling of the area under marginal-marine, freshwater and terrestrial conditions during the Holocene. The deposits reach their greatest thickness of about $30 \mathrm{~m}$ in the seaward region and wedge out toward the Pleistocene hinterland.

These unconsolidated coastal deposits are characterized by lateral zonation.In the seaward region, only marginal-marine and brackish clastic sediments are present overlying a basal peat layer in some places. In the central part of the plain, the deposits consist in general of an alternation of brackish sediments and peat layers. Toward the Pleistocene hinterland, the deposits are formed by only a basal peatlayer overlain by a cover of clastic brackish sediments, while at the very border of the outcropping Pleistocene area, the cover of brackishmarine sediments forms the entire Holocene sequence.

Such lateral zonation, which is typical for the coastal plains of the Southern North Sea, led to the elaboration of a lithological classification of coastal deposits based on the vertical succession and lateral interfingering of clastic sediments and peat (Barckhausen et al., 1977,
Streif, 1978 \& Baeteman, 1981b).

The classification consists of complexes and sequences (fig. 2). In the seaward region the deposits belong to the clastic complex bearing one sequence, viz. the clastic sequence, possibly underlain by the basal peat layer, represented as organic basal sequence. In the central part of the plain, labelled as transition zone, the deposits, characterised by clastic sediments and intercalated peat layers, are grouped into the interfingering complex with the following sequences as further subdivision: lower clastic, splitting up, upper clastic and possibly organic basal sequence. The cross-sections (fig. 5,6 \& 7) clearly demonstrate the occurrence of the splitting up sequence in the central part of the plain, while toward the south, this sequence only consists of one peat layer which moreover finally merges with the basal peat. The seaward region, on the other hand, is characterized by less, and especially thinner peat layers.

The organic basal sequence on the one hand and the splitting up sequence, bearing one or more peat layers, on the other hand, provide the opportunity of reconstructing the chronology of the coastal development.

\section{3 - BASAL PEAT}

The term basal peat indicates the peatlayer occurring at the base of the coastal Holocene sequence. Former researchers were always troubled by doubts wether basal peat is occurring or not in the Belgian coastal plain (Baeteman, 1983). In fact its stratigraphical position and chronology was not well understood. Basal peat was assumed to be of only Preboreal or Boreal age and it ought to occur at great depths. It should be mentioned that only very few and moreover very surficial data were available at the time these conclusions were put forward. Besides, the basal peat very often has been confused with the uppermost intercalated peat layer (see below) in the areas close to the landward border of the plain. In these locations basal peat can reach a thickness up to $1.5 \mathrm{~m}$ and it is indeed occurring at about the same altitude as the uppermost intercalated peat layer. However, from its stratigraphical position, viz. at the base of the Holocene sequence, the peat layer must be regarded as basal peat.

The basal peat shows different facies. Except for the areas close to the Pleistocene hinterland, it is mostly restricted to a humic soil horizon in the top of the Pleistocene sediments.

However, the basal peat is completely absent in a very narrow zone adjacent to the outcropping Pleistocene deposits which are at a too high elevation for the development of it (fig. 3). The same situation is occurring in the southwestern part of the plain.

But in well delimited zones the basal peat is absent due to erosional incisions. The incisions are observed even far inland, and are the result of tidal channels which eroded several metres in the Pleistocene deposits. The basal peat is also lacking in the very seaward part where the Pleistocene deposits are almost completely eroded and in some locations incisions into the Eocene deposits are observed.

The radiocarbon dates from the basal peat are indicated on profiles delineating the topography of the Pleistocene deposits (fig. $4 \& 1$ ). The altitudes are given in Belgian ordnance datum (TAW) where $0 \mathrm{~m}$, corresponding to LLWS (Lowest low water spring), is $2.33 \mathrm{~m}$ below 0m NAP and below 0m NGF.

The deepest basal peat recorded, viz. - $16.97 \mathrm{~m}$ to $16,64 \mathrm{~m}$ (fig. 4, borehole Sh, profile 3), is observed in the seaward area in a pre-existing depression of the Pleisto- 


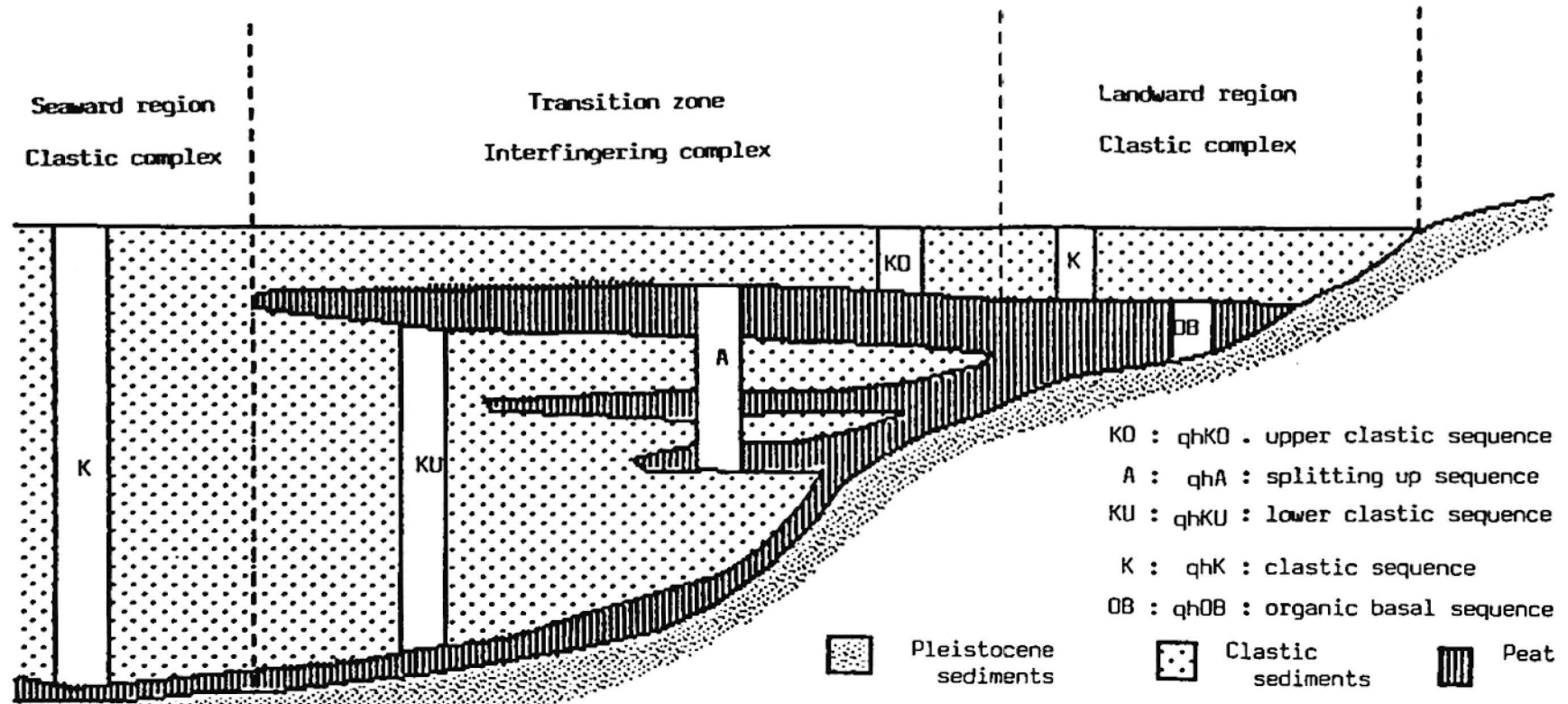

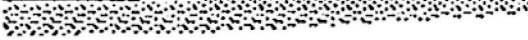

Fig. 2: Schematic cross-section of the Holocene deposits with indication of the complexes and sequences (Redrawn from Baeteman \& Van Strijdonck, 1989).

Fig. 2: Coupe schématique des dépóts holocènes représentant les séquences et les complexes sédimentaires (redessinée d'après Baeteman et Van Strijdonck, 1989).

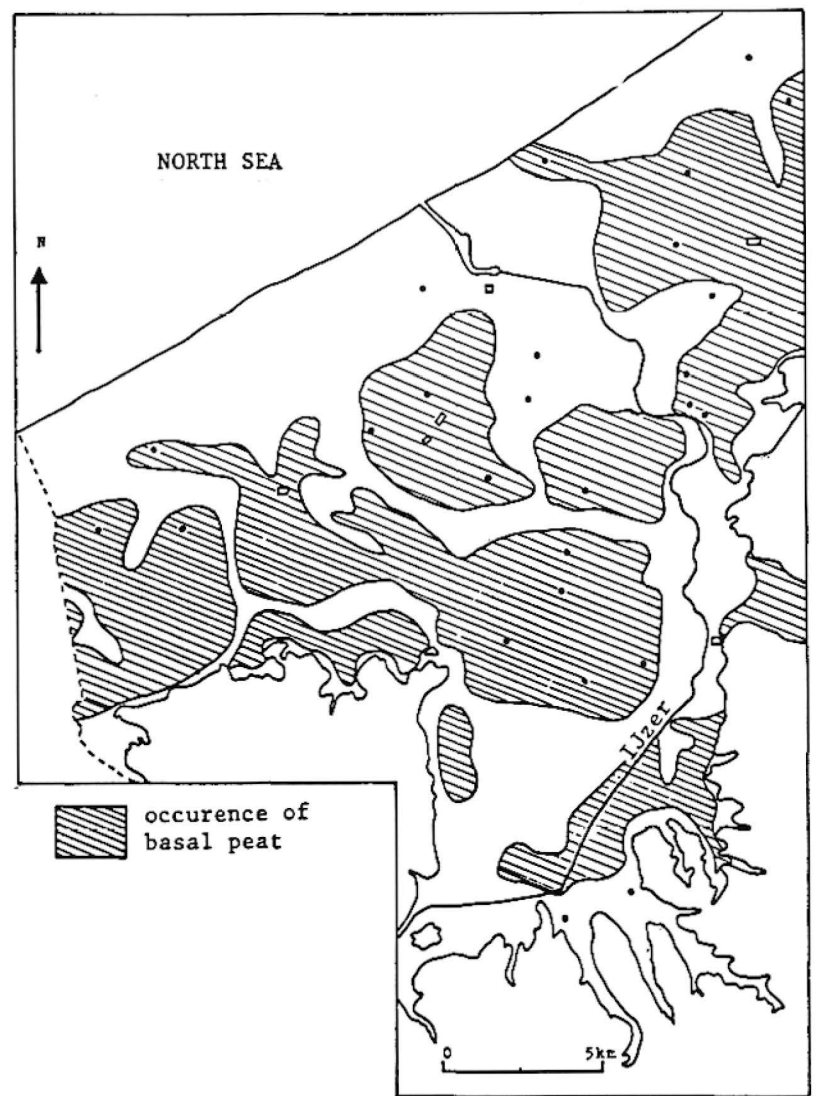

Fig. 3: Distribution map of the major areas where basal peat is occurring. Due to the high altitude of the Pleistocene subsurface, the basal peat is absent in a very narrow zone adjacent to the landward border of the plain as well as in the southwestern part. The absence in the seaward area and in the well delimited zones in the result of erosion (Redrawn from Baeteman \& Van Strijdonck, 1989).

Fig. 3: Carre de distribution des principales zones où se trouve presente la tourbe basale. A cause de l'altinde élevée de la surface pléistocène. la tourbe basale est absente dans une zone étroite le long de la bordure de la plaine, du côté de la terre ainsi que dans la partie sud-ouest. Son absence dans la zone située prés de la mer et dans certaines zones bien délimitées est due d̀ l'érosion (redessinée d'après Baeteman et van Strijdonck, 1989).

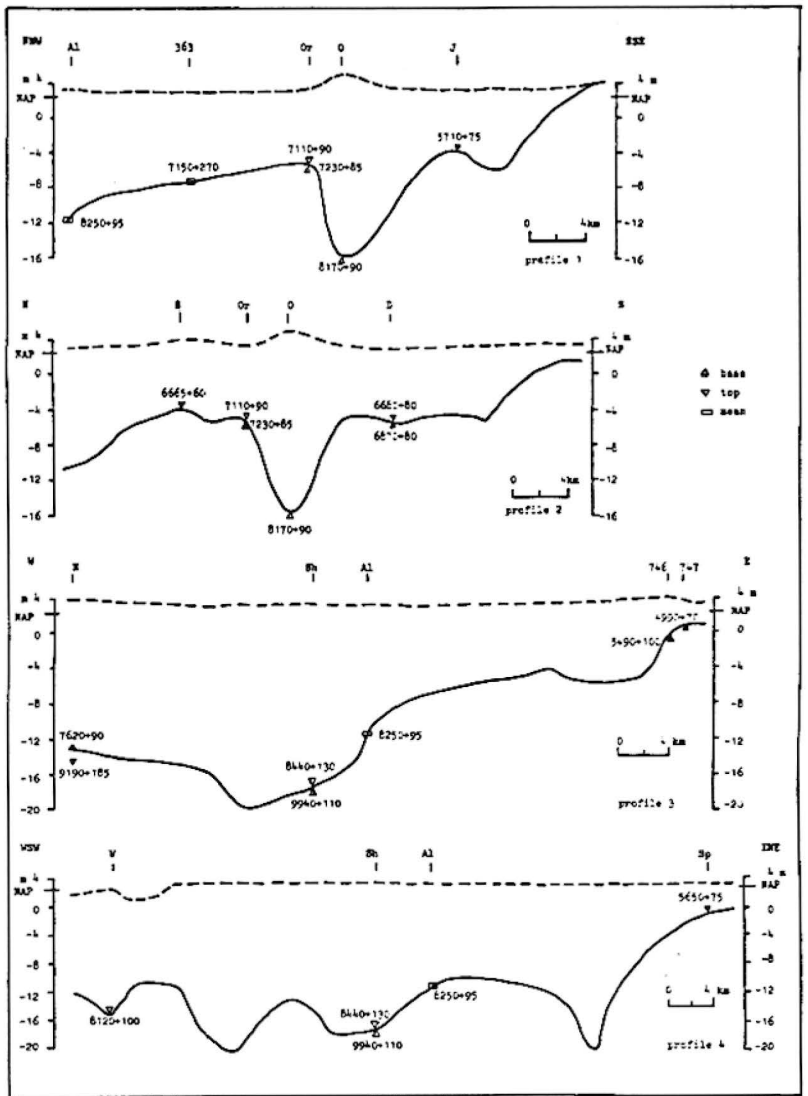

Fig. 4: Profiles demonstrating the relation of the age of the basal peat with the altitude of the Pleistocene subsurface. More details about the topography of the Pleistocene subsurface are shown in the cross-sections (Redrawn from Baeteman \& Van Strijdonck, 1989).

Fig. 4: Profils montrant la relation entre l'âge de la tourbe basale et l'altitude de la surface pléstocène. Plus de détails concernant la topographie de la surface pleistocène sont foumis sur les coupes des figures suivantes (redessinée d'après Baeieman et Van Strijdonck, 1989). 
cene subsurface and dated at $9940 \pm 110 \mathrm{BP}$ (base) and $8440 \pm 130$ BP (top). Still in the same depression in the seaward area, but on a higher level $(-11.34 \mathrm{~m}$, borehole $\mathrm{Al})$, a date of $8250 \pm 95 \mathrm{BP}$ (mean) was obtained. In the landward extension of the same depression, the base of the basal peat $(-15,60 \mathrm{~m}$, borehole 0 , profile 1 and 2$)$ is dated at $8170 \pm 90 \mathrm{BP}$. At about the same altitude the top of a basal peat ( $-15.17 \mathrm{~m}$, borehole $\mathrm{W}$, profile 4$)$, although located in the seaward area, revealed a similar age: $8120 \pm 100 \mathrm{BP}$.

At one site in the very western part of the plain, the base of the basal peat observed at $-13.71 \mathrm{~m}$ to $-13.75 \mathrm{~m}$ is dated at $7620 \pm 90 \mathrm{BP}$. Nearly half a metre below this peat, a humic to peaty sand is occurring, the top of which revealing also a Holocene age $(9190 \pm 185 \mathrm{BP})$. It is quite probable that the lower peaty layer is younged by contamination from the basal peat and therefore is to be considered as Younger Dryas. However, only palynological investigation can be conclusive about that.

A second group of dates (table 1) was obtained from the area more landward where the Pleistocene subsurface is at an altitude between about $-4 \mathrm{~m}$ and $-5 \mathrm{~m}$. The age of the basal peat from borehole 363 ranges in the same group, but the peat is occurring at a much greater depth. It should be remarked that here the whole of the peat layer was sampled and that the datation shows a large standard error.

A third group of dates (table 2) was obtained from the area almost adjacent to the landward border of the plain. In this area, where the top of the Pleistocene deposits is at an altitude between $-2.5 \mathrm{~m}$ to $+1 \mathrm{~m}$, the basal peat is very well developed. in the very northeastern part of the plain (e.g. borehole No; fig. 1) a $2.5 \mathrm{~m}$ thick basal peat developed apparently continuously without being interupted by brackish-marine sedimentation for about 3500 radiocarbon years.

The series of radiocarbon ages from the basal peat shows a rather consistent gradient in relation to the depth of the Pleistocene subsurface. The dates indicate that an unidirectional landward and upward shift of the coastal environment took place under the influence of a rapidly rising sea level. A situation which is very similar to all other coastal plains of the Southern North Sea (Streif, 1989, Shennan, 1989). However, when plotted on most of the current sea-level curves from the Southern North Sea lowlands (e.g. Shennan, 1989, Streif, 1989, van de Plassche, 1982), significant differences turn out. The Belgian data are systematically lying above the curve. Wether this reflects a different subsidence, consolidation or crustal effect, is still to be investigated.

The basal peat is directly covered by mudflat sediments in all the boreholes, except in location Sh and No (fig. 1), where lagoonal sediments (sensu Streif, 1971) of $1 \mathrm{~m}$ and $20 \mathrm{~cm}$ thick respectively, overlie the peat. From this information it can be assumed that sea level was close to at least $-18 \mathrm{~m}$ (NAP) at about $8400 \mathrm{BP}$. The data also give evidence that tidal flats developed in the deepest parts of the plain as from about $8100 \mathrm{BP}$.

\section{4 - INTERCALATED PEAT LAYERS}

The tidal flats continued to develop until 7000 BP. As from then peat growth initiated, however only in very restricted zones. The oldest and deepest known intercalated peat layers are observed in valley-like depressions in the pre-Holocene surface as clearly demonstrated by the cross-sections (fig. $5 \& 6$ ) which form a more elaborated picture of the profiles $1 \& 2$ (fig. 1). The cross-sections delineate the entire Quaternary sequence
Table 1.

Second group of radiocarbon dates from the basal peat occurring at an altitude between ca $-5 \mathrm{~m}$ and $-4 \mathrm{~m}$.

\begin{tabular}{|c|c|c|c|}
\hline borehole & lab. $\mathrm{nr}$ & y B.P. & altitude $(m)$ \\
\hline \multirow[t]{2}{*}{363} & HV 8797 L & $7155 \pm 250$ & -7.00 (mean) \\
\hline & HV 8798 J & & \\
\hline Or & IRPA 533 & $7230 \pm 85$ & -5.20 to -5.23 (base) \\
\hline Or & IRPA 534 & $7110 \pm 90$ & -5.13 to -5.17 (top) \\
\hline D & IRPA 542 & $6870 \pm 80$ & -5.07 to -5.10 (base) \\
\hline D & IRPA 541 & $6680 \pm 80$ & -4.90 to -4.93 (top) \\
\hline $\mathrm{S}$ & IRPA 927 & $6665 \pm 60$ & -3.67 to -3.86 (top) \\
\hline
\end{tabular}

Table 2.

Third group of radiocarbon dates from the basal peat occurring at altitudes between $-2.5 \mathrm{~m}$ to $+1 \mathrm{~m}$.

\begin{tabular}{|lccc|}
\hline borehole & Iab. $\mathrm{nr}$ & $y$ B.P. & \multicolumn{1}{c|}{ altitude (m) } \\
742 & IRPA 725 & $5970 \pm 120$ & -2.10 to -2.25 (base) \\
746 & IRPA 722 & $5490 \pm 100$ & -0.56 (base) \\
747 & IRPA 723 & $4990 \pm 70$ & +0.90 (base) \\
La & IRPA 251 & $5310 \pm 190$ & -1.20 (base) \\
$\mathrm{No}$ & IRPA 729 & $5770 \pm 100$ & -2.30 to -2.37 (base) \\
$\mathrm{No}$ & IRPA 730 & $2220 \pm 55$ & +0.21 to +0.17 (top) \\
$\mathrm{Sp}$ & IRPA 519 & $5650 \pm 75$ & -1.04 (top) \\
La & IRPA 250 & $5100 \pm 140$ & -0.90 (top) \\
$\mathrm{J}$ & IRPA 617 & $5710 \pm 75$ & -2.58 to 2.70 (top) \\
\hline
\end{tabular}

in order to better understand the infilling and erosional processes during the Holocene. The Pleistocene deposits, however, are not differentiated yet. Anyhow it is clear that the topography of the subsurface, showing a substantial relief, influenced to a large extent the Holocene infilling.

From two depressions the lowest intercalated peat layer was dated $7030 \pm 85 \mathrm{BP}$ and $7000 \pm 80 \mathrm{BP}$ for the base and $6750 \pm 80 \mathrm{BP}$ for the top (cross-section 2, fig. 6). Although the age of peat initiation is similar, both depressions bear a different history.

The depression in the central part of the plain is initially filled with sandflat sediments covering the basal peat. In the southernmost depression, the Holocene sequence lies directly on the Eocene clay. The sediments underlying the peat, however, are from fluvial origin. Besides, the borehole evidence from this particular area points to the existence of a significant fluvial system which eroded Pleistocene sequences 5 to $10 \mathrm{~m}$ thick. Some of the eroded zones are filled with a 9 m thick nearly continuous peat sequence covering Holocene fluvial sediments. Further research is needed to be decisive about the period(s) this fluvial system was active.

As from an altitude of about $\mathbf{- 3 . 5} \mathrm{m}$ until about $+\mathbf{3 . 0}$ $\mathbf{m}$, the coastal sequence consists of an alternation of peat layers and tidal flat sediments, a sequence which is usually called the typical cyclic formation of coastal deposits. This alternation can not be regarded as a simple alternation of regressions and transgressions and 


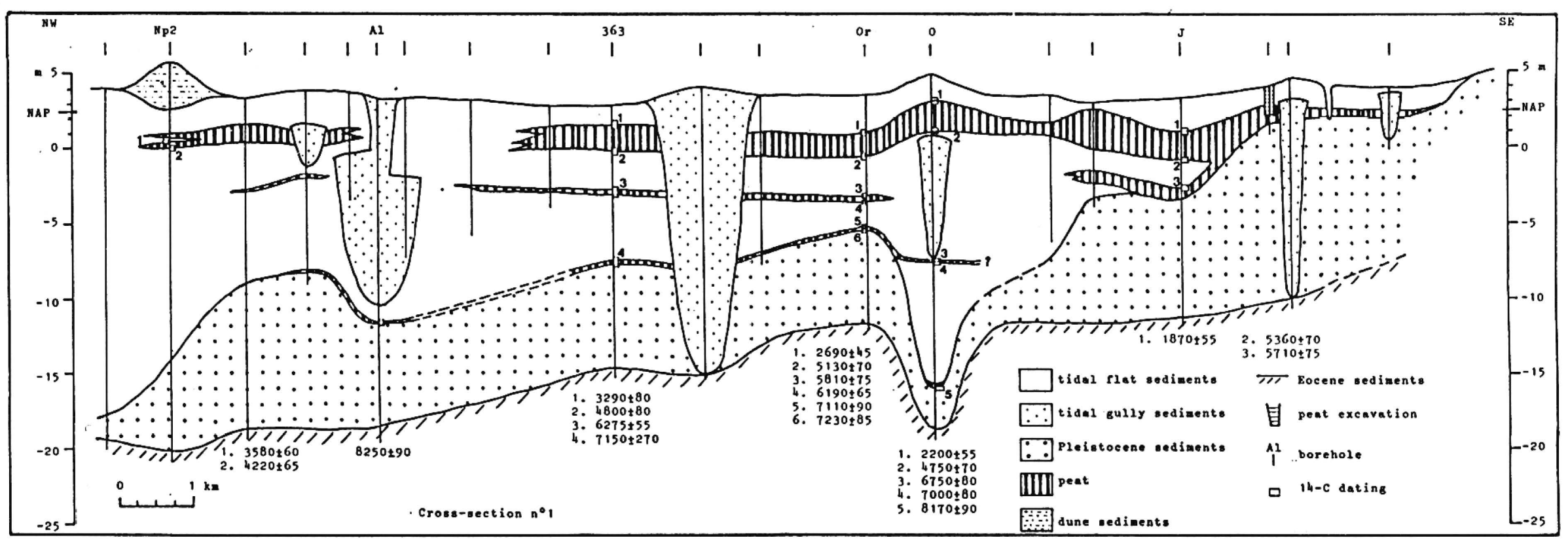

Fig. 5: Cross-section of the Quaternary sequence perpendicular to the present coastline indicating the basal and intercalated peat datings. The cross-section clearly shows the well developed uppermost intercalated peat in the central part of the plain merging with the basal peat in the east (Redrawn from Baeteman \& Van Strijdonck, 1989).

Fig. 5: Coupe dans la séquence quaternaire, perpendiculaire d̀ l'actuelle ligne de côte, indiquant les dates des tourbes basales et intercalaires. La coupe montre nettemen le bon developpement de la tourbe intercalaire supérieure dansla partie centrale de la plaine et sa jonction d la tourbe basale dans la partie est (redessinée d'après Baeteman et Van Strijdonck, 1989). 


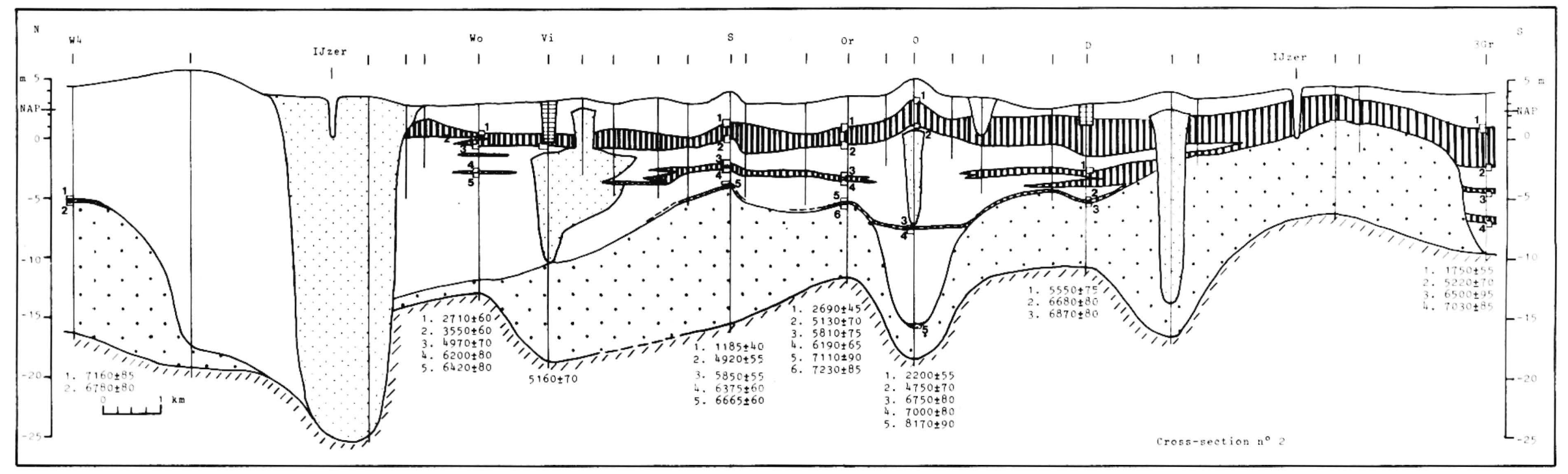

Fig. 6: Cross-section clearly showing the typical cyclic alternation of peat and clastic sediments in the central part of the plain as well as the deeper intercalated peat layers occurring in pre-Holocene valley-like depressions. Different phases of development of tidal channels are demonstrated, two of them eroded deeply the

Fig. 6: Coupe montrant nettement l'alternance cyclique, typique, de tourbe et de sédiments clastiques dans la partie centrale de la plaine ainsi que les tourbes intercalaires les plus profondes restreintes dans des dépressions de la surface pré-Holocène, comparables à des vallées. Différentes phases de développement des chenaux tidaux apparaissent, deux d'entre eux érodent profondément la surface pléstocène (redessinée d'après Baeteman et Van Strijdonck, 1989). 
it is in no way synonymous with a fall and rise in sea level. It is true, the alternating clastic and biogenic layers can be used to infer sea-level movements, but they also reflect recent earth movements, climatic changes, coastal processes and changes in sediment origin and supply from drainage basins and the continental shelf (Tooley, 1982). It never can be repeated enough, as clearly stated by Streif (1982) and Kraft \& Chrzastowski (1985), that the vertical changes of the sea level are only one component among a great variety of factors which influence the development of a retreating or prograding coastline.

The ambiguity of the mearings of transgression and regression has been thoroughly discussed by several authors, especially for the sake of interpreting sea-level related data and establishing regional correlations (Shennan, 1982a, 1982b, 1983, 1986, 1987, Shennan et al., 1983; Streif, 1979, 1982; Ludwig et al., 1981 ; Baeteman, 1981a, 1981b, 1987a; Tooley, 1982; Haggart, 1988). To avoid any further misinterpretation and inconsistencies in labelling the alternation of peat and clastic sediments, the terms transgressive and regressive overlaps are used as descriptive terms in which no process is implied (Streif, 1979, Shennan, 1982a, Tooley, 1982).

Until now, 4 different peat layers were observed, but not always regularly at the same altitude or with the same extension and thickness. However, the peat layer found at an altitude ranging between $-2.5 \mathrm{~m}$ and $-3.0 \mathrm{~m}$ shows a rather regular extension (fig. 5 \& 6). It was sampled at four locations (table 3 ) revealing ages between 6400 and $6200 \mathrm{BP}$ for the base and 6200 and 5550 BP for the top. This peat growth lasted between 380 and 220 radiocarbon years.

Comparing the dates of this intercalated peat, it seems that the peat growth occurred slightly earlier in the seaward than in the landward part of the plain, although the number of data is far too insufficient to be conclusive on that.

The uppermost peatlayer of the series of intercalated peats is the most extended and thickest one. It occurs throughout nearly the entire plain, even beyond the present shoreline. Its thickness almost reaches $1 \mathrm{~m}$ to nearly $2 \mathrm{~m}$ and generally it is situated between the altitudes of $\mathrm{ca}-0.5 \mathrm{~m}$ and $+1 \mathrm{~m}$. In the Belgian literature it is usually referred to as surface peat. The radiocarbon dates from this uppermost intercalated peat layer are compiled in table 4 and indicated on crosssections $1,2 \& 4$ (fig. 5, 6 \& 7).

The radiocarbon dates from the base of this uppermost intercalated peat layer show an age range of 5360 $\pm 70 \mathrm{BP}$ to $4220 \pm 65 \mathrm{BP}$. However, the greatest number of dates reveals an age in a much smaller range, i.e. 4700 BP - $5220 \mathrm{BP}$ in which a concentration of dates is

Table 3.

Radiocarbon dates from the intercalated peat occurring at an altitude between $-3.0 \mathrm{~m}$ and $-2.5 \mathrm{~m}$.

\begin{tabular}{|lccccc|}
\hline borehole & lab.nr & y B.P. & & altitude (m) \\
Wo & IRPA 561 & $6420 \pm 80$ & -2.73 to -2.77 (base) \\
Wo & IRPA 559 & $6200 \pm 80$ & -2.63 to -2.67 (top) \\
Wo & IRPA 558 & $6160 \pm 80$ & -2.63 (wood at top) \\
S & IRPA 834 & $5850 \pm 55$ & -2.14 to -2.19 (top) \\
S & IRPA 871 & $6375 \pm 60$ & -2.51 to -2.65 (base) \\
Or & IRPA 831 & $6190 \pm 65$ & -3.33 to -3.38 (base) \\
Or & IRPA 612 & $5810 \pm 75$ & -2.95 to -3.01 (top) \\
D & IRPA 613 & $5550 \pm 75$ & -2.54 to -2.59 (top) \\
\hline
\end{tabular}

Table 4.

Radiocarbon dates from the uppermost intercalated peat.

\begin{tabular}{|c|c|c|c|c|}
\hline borehole & top (y B.P.) & IRPA lab nr & base (y B.P.) & IRPA labnr \\
\hline Wo & $2710 \pm 60$ & 859 & $4970 \pm 70$ & 560 \\
\hline$v i$ & $\cdots$ & & $5160 \pm 70$ & 562 \\
\hline s & $1185 \pm 40$ & 826 & $4920 \pm 55$ & 848 \\
\hline \multirow[t]{2}{*}{ Or } & $2230 \pm 40$ & 847 & $5130 \pm 70$ & 532 \\
\hline & $2690 \pm 45$ & 832 & & \\
\hline 0 & $2200 \pm 55$ & 867 & $4750 \pm 70$ & 868 \\
\hline $3 \mathrm{Gr}$ & $1750 \pm 55$ & 521 & $5220 \pm 70$ & 531 \\
\hline Np 2 & --- & & $4220 \pm 65$ & 726 \\
\hline J & $1870 \pm 55$ & 537 & $5360 \pm 70$ & 538 \\
\hline Sh & -- & & $4540 \pm 65$ & 682 \\
\hline Wa & $1610 \pm 55$ & 872 & $\cdots$ & \\
\hline W 1 & $\cdots$ & & $5125 \pm 55$ & 846 \\
\hline vi & $2580 \pm 60$ & 512 & $4700 \pm 70$ & 865 \\
\hline Sp 2 & $\cdots$ & & $4860 \pm 70$ & 518 \\
\hline Moe & $\cdots$ & & $4830 \pm 70$ & 564 \\
\hline
\end{tabular}

observed between 4700 BP - 4970 BP and $5130-5160$ BP.

The two youngest dates happen to come from locations in the seaward area (borehole Sh \& Np2); the older dates were obtained from the peat occurring in the very landwart part of the plain (borehole J \& $3 \mathrm{Gr}$, crosssection $1 \& 2$, fig. 1).

Concerning the radiocarbon dates from the top of the peat, there is some discrepancy between the present results and previously published radiocarbon dates (Baeteman, 1981a, Baeteman, 1985, Baeteman 1987b, Baeteman \& Verbruggen, 1979, Baeteman et al., 1981). The dates were grouped in two series: one ranging between 3000 and $3300 \mathrm{BP}$ and the second one ranging between 2000 and $2300 \mathrm{BP}$. Therefore it was assumed that after a general halt of the peat growth at about 3200 BP, locally there was a resume until $2000 \mathrm{BP}$. However from the present results, it can be concluded that generally the peat growth stopped between 2700 and 2200 $\mathrm{BP}$, while in the landward part of the plain it continued until 1900 to $1600 \mathrm{BP}$.

The very young age of $1185 \pm 40 \mathrm{BP}$ (borehole S) forms a striking exception, and the date is suspected to be younged by modern rootlet contamination. The top of the peat in location Or was sampled in two different boreholes at a distance of only few metres, and yet revealed a significant difference in age of nearly 500 radiocarbon years. Although not apparent, the top of the peat most probably has been eroded.

In certain zones of the seaward part of the plain, a very thin clay intercalation in the generally thick peat sequence is observed. The radiocarbon dates of the trangressive overlap(s) are shown on fig. 8. The dates from the transgressive overlap in borehole Np2 and regressive overlap in borehole Wo reveal similar ages. The age of the regressive overlap is supported by a sample taken from a regressive overlap in a temporary outcrop in Wulpen (Wu, fig. 1) giving an age of $3490 \pm 60 \mathrm{BP}$. On the other hand in the northeastern zone of the surveyed area (location Vl, fig. 1), a different sequence of this intercalated peat was observed. The peat layer, reaching 


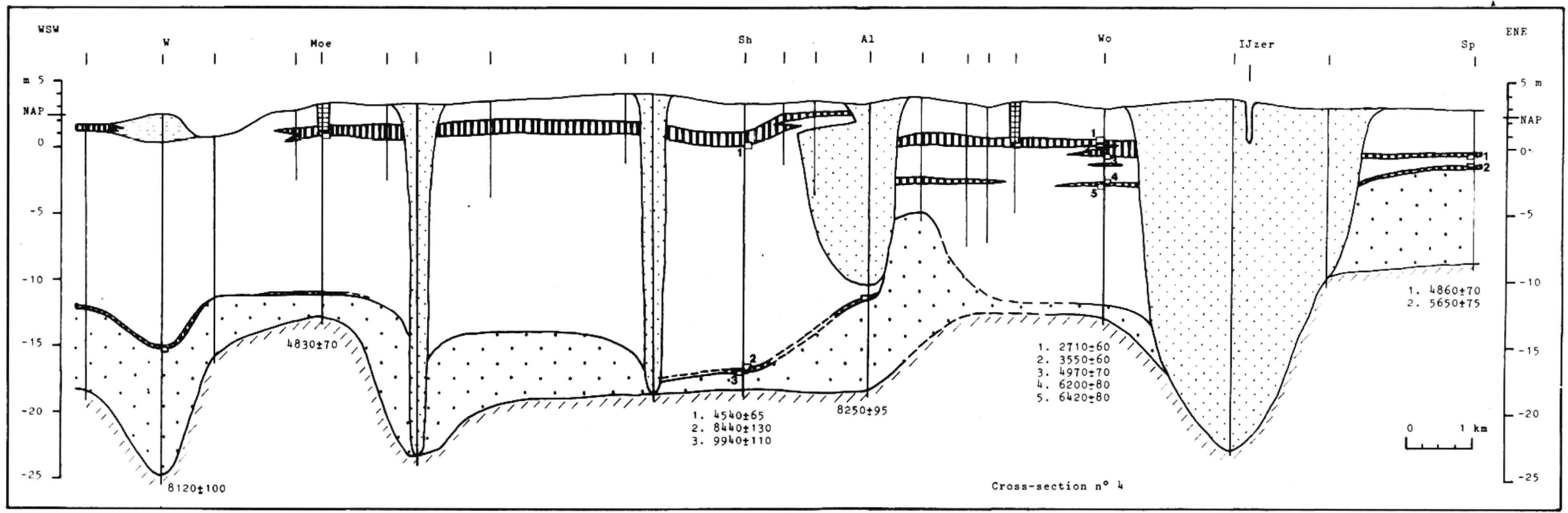

Fig. 7: Cross-section in the seaward part of the plain where less intercalated peat layers are found. In the eastern part the erosion by a tidal channel, seriously modifying the Eocene and Pleistocene topography, is demonstrated (Redrawn from Baeteman \& Van Strijdonck, 1989).

Fig. 7: Coupe de plaine dans la partie proche de la mer où se trouvent moins de couches de tourbe intercalaire. Dans la partie orientale, l'érosion par un chenal de marée modifie sérieusement la topographie eocène et pléstocène (redessinée d'après Baeteman et Van Strijdonck, 1989). 


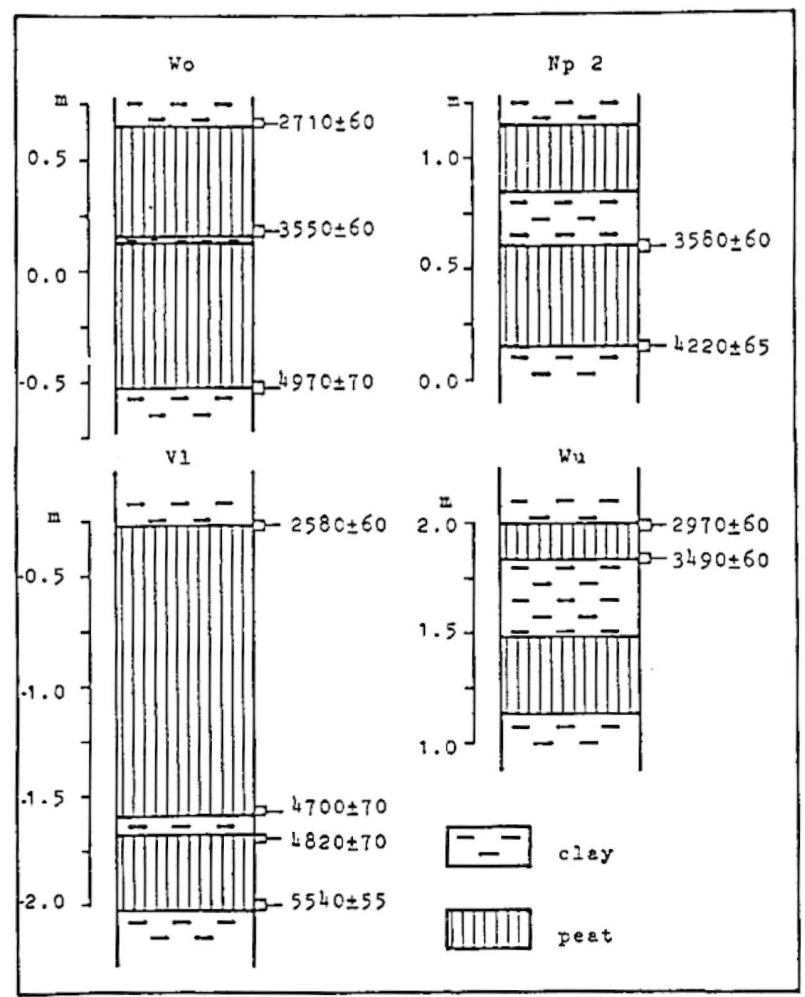

Fig. 8: Datings of the transgressive overlaps in the uppermost peat sequence (in y. B.P.) (Redrawn from Baeteman \& Van Strijdonck, 1989).

Fig. 8: Dates des recouvrements transgressifs dans la séquence supérieure de tourbe intercalaire (en années B.P.) (redessinée d'après Baeteman et Van Strijdonck, 1989).

a thickness of $1.34 \mathrm{~m}$ is underlain by a few-cm thick reedswamp mud, followed by another $36 \mathrm{~cm}$ thick peat. The dates of the regressive and transgressive overlap indicate that between $4820 \pm 70 \mathrm{BP}$ and $4700 \pm 70 \mathrm{BP}$ a brief period of clastic sedimentation took place and a transgressive overlap is recorded in the lower part of the peat sequence.

What event(s) exactly caused the termination of the peat growth, is still not resolved (Baeteman \& Verbruggen, 1979). In the locations where the top of the peat is not eroded, a thin organic mud layer is covering it. Most of the time, however, tidal flat deposits are directly overlying the peat with an erosional contact. The time lag between the termination of the peat growth and the start of the tidal flat development is still unknown.

Anyhow, a significant event created completely different environmental conditions in the entire plain, even beyond the former landward border; the shoreline shifted landwards. Tidal flat sediments were deposited in which no regressive overlaps anymore are observed. New tidal channels originated, some of which eroded deeply the sedimentary sequence, even far landward. Besides, in some locations the original morphology of the Pleistocene subsurface has been seriously modified (fig. 6).

The development of this tidal flat environment, evolving in the end to salt marsh, represents the last phase of infilling of the plain before men started to reclaim and protect it from the sea.

\section{5 - FINAL CONSIDERATIONS}

The development of a coastal plain can be understood only by unraveling the spatial distribution of its different sedimentary and sedentary units. These units reflect the response of the coastal processes in the gradual development or abrupt change of the depositional environments producing the infill of the plain. Therefore it is necessary to know the development of these environments as well in a lateral as in a vertical sense. The within-area-correlation can then be established by means of the lithogenetic classification system matching with the general sequence of events. Such a system only contributes to the understanding of the history of infill, rather then an imposed static stratigraphy. The linkage of the lithogenetic classification system with the age dates of the several peat layers, ultimately provides the opportunity of reconstructing the chronology of the coastal development.

Besides the rate of the sea-level rise, the topography of the pre-Holocene surface influenced to a large extent the infilling of the plain.

From the time-depth data of the termination of the basal peat, it can be concluded that the sea level was close to at least - $18 \mathrm{~m}$ (NAP) at about 8400 B.P. Since 8100 B.P. tidal flats start to develop in the lowest lying parts of the area. Only clastic sediments were deposited, reflecting the rapid rising sea level. At 7000 B.P. a first peat growth initiated, although only in restricted areas, such as the valley-like depressions in the pre-Holocene surface.

Since 6400 B.P., however, general peat growth is observed over nearly the entire plain, reflecting the decrease in the rise of the sea level. This peat layer represents the onset of what is usually called the typical cyclic formation of coastal deposits where peat repeatedly came into being alternating with the deposition of tidal flat sediments. As from the beginning of the period of cyclic formation, tidal flat sediments were deposited far landward. The alternation of peat and sediments is not always that regular, because while peat was accumulating in certain parts of the area, tidal flats continued to develop in others contemporaneously. Moreover the initiation, resp. termination of a peat accumulation differs laterally. Hence it is alway critical to put forward general periods of peat growth. But between ca 5200 B.P. and 2200 B.P. ideal conditions for peat growth prevailed as nearly the entire plain was characterized by it. This peat growth represents a significant time span in the infill of the plain as it lasted nearly 3500 and 220014 Cyears in respectively the landward and seaward part of the area. The cyclic formation with the intercalated peat layers generally came to an end in the time interval of $2700-2200$ B.P., and in more landard areas, between 1900 and 1600 B.P.

The uppermost peat layer is covered by tidal flat deposits representing a significant change in the development of the infill of the plain. The depositional conditions must have changed drastically as the tidal channels renewed their activity and new ones originated, causing severe erosion of the depositional sequence even far landward.

\section{REFERENCES}

BAETEMAN, C., 1981a - De Holocene ontwikkeling van de Westelijke kustvlakte (België). Proefschrift, 297 p., Brussel.

BAETEMAN, $C_{n}, 1981 b$ - An alternative classification and profile type map applied to the Holocene deposits of the Belgian coastal plain. Bull. Belg. Ver. geol., 90, 4, 257-280.

BAETEMAN, C, 1983 - De Holocene sedimenten van de westelijke kustvlakte: een analyse van de Belgische litteratuur. Prof. Paper, 9 , 204, 45 p., Brussel. 
BAETEMAN, C., 1985 - Development and evolution of sedimentary environments during the Holocene in the Western coastal plain of Belgium. Eiszeitalter u. Gegenwart, 35, 23-32.

BAETEMAN, $C_{m}$ 1987a - Mapping a coastal plain. Problems concerning mapping units. Geobound, 1, 1, 3-9.

BAETEMAN, Co, 1987b - Ontstaan en evolutie van de Kustvlakte (tot 2000 jaar voor heden). In: Thoen, H. (ed.): De Romeinen langs de Vaamse kust, uitgave Gemeentekrediet, 18-21.

BAETEMAN, C. \& VERBRUGGEN, C, 1979 - A new appraach of the so-called surface peat in the westem coastal plain of Belgium. Prof. Paper, 11, 167, 21 p., Brussel.

BAETEMAN, C., CLEVERINGA, P. \& VERBRUGGEN, C., 1981 Het paleomilieu rond het Romeins zoutwinningssite van Leffinge. Prof. Paper, 7, 186, 33 p., Brussel.

BAETEMAN, C. \& VAN STRIJDONCK, M., 1989 - Radiocarbon dateson peat from the Holocene coastal deposits in West Belgium. In: Baeteman, C. (ed.): Quaternary sea level investigations from Belgium. A contribution to IGCP Project 200. Professional Paper of the Belgian Geological Survey, 1989/6 nr 241, 59-91.

BARCKAUSEN, J., PREUSS, H. \& STREIF, H, 1977 - Ein lithologisches Ordnungsprinzip für das Küstenholozän und seine Darstellung in Form von Profiltypen. Geol. J., A44, 45-77.

HAGGART, B.A, 1988 - A review of radiocarbon dates on peat and wood from Holocene coastal sedimentary sequences in Scotland. Scott. J. Geol., 24 (2), 125-144.

KRAFT, J.C. \& CHRZASTOWSKI, NJ, 1985 - Coastal stratigraphic sequences. In: Davis, R.A. Jr. (ed.): Coastal sedimentary environments. Springer Verlag, 625-659.

LUDWG, G, MULLER, H. \& STREIF, H., 1981 - New dates on Holocene sea-level changes in the German Bight. In: Nio, S.-D., Shüttenhelm, R.T.E. \& van Weering, Tj.C.E. (eds.): Holocene marine sedimentation in the North Sea Basin, Spec. Publ., n 5 , I.A.S., Blackwell scientific Publications, 211-219.

SHENNAN, I. 1982a - Interpretation of Flandrian sea-level data from the Fenland. England. Proc. Geol. Ass., 93 (1), 53-63.

SHENNAN, I. 1982b - Problems of correlating Flandrian sea-level changes and climate. In: Harding, A.F. (ed.): Climatic change in Later Prehistory, Edinburgh University Press, 52-67.
SHENNAN, In, 1983 - Flandrian and Late Devensian sea-level changes and crustal movements in England and Wales. In: Smith, D.E. \& Dawson, A.G. (eds.): Shorelines and Isostasy, Academic Press, London, 255-283.

SHENNAN, I, 1986 - Flandrian sea-level changes in the Fenland. II: Tendencies of sea-level movement, altitudinal changes, and local and regional factors. Joumal of Quatemary Science, 1 (2), 155-179.

SHENNAN, I, 1987 - Global analysis and correlation of sea-level data. In: Devoy, R. (cd.): Sea surface studies, a global view, Croom Helm, 198-230.

SHENNAN, I, 1989 - Holocene sea-level changes in the North Sea Region. In: Tooley \& Shennan (eds.): Sea-level changes. Basil Blackwell Ltd, Oxford, 109-151.

SHENNAN, I. TOOLEY, MJ., DAVIS, MJ. \& HAGGART, BA., 1983 - Analysis and interpretation of Holocene sea-level data. Nature, 302, $5907,404-406$.

STREIF, H, 1971 - The results of stratigraphical and facial investigations in the coastal Holocene of Woltzeten/Ostfriesland, Germany. Geol. Föreningen i Stockholm Förhandlingar, 94, 2, 281299.

STREIF, $H_{,}, 1978$ - A new method for the representation of sedimentary sequences in coastal regions. Proc. 16th Coastal Engineering Conference, Hamburg, 1245-1256.

STREIF, H, 1979 - Cyclic formation of coastal deposits and their indications of vertical sea-level changes. Oceanis, 5, Fasc. HorsSerie, 303-306.

STREIF, $H_{,}, 1982$ - The occurrence and significance of peat in the Holocene deposits of the German North Sea coast. In: de Bakker, H. \& van den Berg, M.W. (eds.): Proceedings of the symposium on peat lands below sea level, ILRI publication, 30, 31-41.

STREIF, H, 1989 - Barrier islands, tidal flats, and coastal marshes resulting from a relative rise of sea level in East Frisia on the German North Sea coast. Proc. KNGMG Symposium «Coastal Lowlands, Geology and Geotechnology, 1987, 213-223.

TOOLEY, M.J, 1982 - Sea-level changes in northern England. Proc. Geol. Ass., 93 (1), 43(51.

VAN DE PLASSCHE, O, 1982 - Sea-level change and water-level movements in the Netherlands during the Holocene. PhD-thesis, Amsterdam, 146 p. 